\title{
A retrospective investigation of the pmx-dhp's efficacy in 88 severe sepsis cases
}

\author{
M Tanaka*, K Ueda, Y Kawazoe, T Yonemitsu, M Kida, Y Shima, S Yamazoe, Y Iwasaki, S Kato, \\ Emergency and Critical Care Medicine \\ From ESICM LIVES 2015 \\ Berlin, Germany. 3-7 October 2015
}

\section{Objective}

To investigate the efficacy of polymyxin-B direct hemoperfusion (PMX-DHP) in terms of improving clinical conditions and life prognosis in severe sepsis cases.

\section{SUBJECTS AND METHODS}

The subjects were 88 cases admitted to our hospital ICU between April 2010 and July 2014 with the diagnosis of severe septic shock requiring continuous norepinephrine injection (Cathecholamine Index $\geqq 10$ ). We investigated PMX-DHP efficacy by retrospectively comparing 63 cases that underwent PMX-DHP with 25 cases that did not.

\section{Results}

The two groups did not differ significantly in age, APACHE II score, SOFA score, infection focus, and bacterial species. The 28 -day mortality was $32 \%$ in the PMXDHP group and $40 \%$ in the non-PMX-DHP group, but this difference was not significant. The $\Delta \mathrm{CAI}$ (the change in Cathecholamine Index 24 hours after PMX-DHP administration) and the infusion volume 24 hours after PMX-DHP administration were significantly different between the two groups. Multivariate analysis identified $\triangle \mathrm{CAI}$ and SOFA score as independent prognostic factors. Sub-analysis showed no significant difference in 28-day mortality in sepsis cases involving the lower-gastrointestinal tracts, but a trend for improvement in 28-day mortality was observed in sepsis cases where the infection focus could not be removed, such as pneumonia, and in severe sepsis cases whose APACHE II score exceeded 25.

\section{Conclusions}

PMX-DHP may improve life prognosis of septic shock cases under certain conditions. We have to clarify the

Wakayama Medical College, Wakayama City, Japan indication criteria for PMX-DHP and accumulate data by additional investigations of severe septic cases to pursue the possibilities for further improvements in life prognosis.

Published: 1 October 2015

doi:10.1186/2197-425X-3-S1-A794

Cite this article as: Tanaka et al:: A retrospective investigation of the pmx-dhp's efficacy in 88 severe sepsis cases. Intensive Care Medicine Experimental 2015 3(Suppl 1):A794.

\section{SpringerOpen $^{\odot}$}

( 2015 Tanaka et al.; This is an Open Access article distributed under the terms of the Creative Commons Attribution License (http:// creativecommons.org/licenses/by/4.0), which permits unrestricted use, distribution, and reproduction in any medium, provided the original work is properly cited.
Submit your manuscript to a SpringerOpen ${ }^{\circ}$ journal and benefit from:

- Convenient online submission

- Rigorous peer review

- Immediate publication on acceptance

- Open access: articles freely available online

- High visibility within the field

Retaining the copyright to your article

Submit your next manuscript at $>$ springeropen.com 